AC 2011-2179: THE DESIGN PROCESS AS AN APPROACH TO UNDERSTANDING ENGINEERING AS A PROFESSION

Rebecca N. Macdonald, University of Alabama

NSF GK-12 Fellow, Doctoral student in Civil Engineering

Beth Todd, University of Alabama

Dr. Beth Todd is an Associate Professor in Mechanical Engineering at the University of Alabama. 


\section{The Design Process as an Approach to Understanding Engineering as a Profession}

Introduction and Background

The importance of furthering science, technology, engineering and math (STEM) in K-12 education remains in the forefront of today's society. Even with years of inclusion, engineering remains an enigma to many pre-college students. The 2008 National Academy of Engineering's report, Changing the Conversation, stated the case that many Americans do not truly understand what engineering is. ${ }^{11}$ Even with hundreds of millions of dollars annually spent on increasing understanding of engineering, efforts to promote engineering have been numerous and widespread yet there has been minimal impact. ${ }^{3,12} \mathrm{~K}-12$ students can readily identify with writers, doctors, scientists, and other careers from their exposure to these fields yet struggle with engineering. Despite all these efforts, research has shown that K-12 students and teachers continue to have a poor understanding of what engineers do..$^{3,4,5,9,10,13}$ Establishing a clear, concise definition of engineering highlighting its uniqueness relative to other technical domains better facilitates teachers and students to grasp the engineering perspective. ${ }^{1,13,16}$ Further students may achieve higher math and science learning when the scientific inquiry process is integrated into a design setting. $8,9,15,17$

In an effort to help facilitate a better understanding of engineering, the University of Alabama has partnered with the Sumter County School System to develop their Engineering Academy. The participating school teachers are introduced to the design process during a summer enrichment program. With the addition of a state sponsored program, Building Alabama, engineering design curriculum modules have been developed to be deployed in schools. While working on these various projects, the authors noticed the similarities yet subtle differences between the design process and the scientific method. K-12 students are taught early on the scientific method and continue to apply it as they proceed towards graduation. This left the authors to wonder:

If the scientific method helps students understand the questioning nature of science, would the addition of the engineering design process help students understand design as a problem solving tool and enhance appreciation of the function of an engineer?

The scientific method enables students to gain insight into a scientist role and logic. In order to get a real feel for the "essence" of engineering, time should be spent teaching students about the engineering design process and to understand the general steps. ${ }^{1,6}$ By fully understanding characteristics of each approach and key differences between them students may improve the recognition and appreciation of both the scientific method and the engineering approach. ${ }^{13}$ Once students gain this understanding, the task of exposing students to the academic disciplines, job functions, and industry utilization that categorize engineers is easier. ${ }^{7}$ The greater the variety of careers students explore the more informed they will be to make their career choices. ${ }^{2}$ The 
integration of mathematics, science, and engineering is central to high school reform efforts that strive to prepare students for both college and career opportunities in engineering. ${ }^{17}$ This process can be immediately applied following a science experiment without need to acquire lesson plans, expensive equipment or supporting materials. This paper discusses the development and implementation of a scientific and engineering classroom activity and assesses the effectiveness of the activity by presenting response data collected from the participants.

\section{Methodology}

In this study engineering design is used in two high school science courses as a problem solving tool that parallels the scientific method. A standard chemistry/physical science lab was selected that clearly demonstrates the scientific method. Upon conclusion the engineering design process was performed as the constraints would allow. The engineering design problem was structured to accommodate the science lab, school facility and capabilities of the participating students. A Pre-Activity and Post-Activity Quiz was given to the students to help measure the effect. The initial quiz was intended to act as a baseline of student knowledge while the final quiz was to show knowledge gained. The open-ended questions stated on the quizzes are shown in Table 1.

Table 1. Pre-activity and Post-Activity Quiz Questions.

\begin{tabular}{|l|l|}
\hline PRE & \multicolumn{1}{|c|}{ POST } \\
\hline $\begin{array}{l}\text { List as many career opportunities that you } \\
\text { are considering currently or in your future. }\end{array}$ & $\begin{array}{l}\text { Are you more or less interested in the fields of } \\
\text { science or engineering after the popcorn lesson? }\end{array}$ \\
\hline $\begin{array}{l}\text { Can you name the major steps of the } \\
\text { scientific method. }\end{array}$ & $\begin{array}{l}\text { Can you name the major steps of the scientific } \\
\text { method. }\end{array}$ \\
\hline $\begin{array}{l}\text { List as many descriptive words you know } \\
\text { about a scientist. }\end{array}$ & $\begin{array}{l}\text { List as many descriptive words you know about a } \\
\text { scientist. }\end{array}$ \\
\hline $\begin{array}{l}\text { Can you name the major steps of the } \\
\text { engineering design process. }\end{array}$ & $\begin{array}{l}\text { Can you name the major steps of the engineering } \\
\text { design process. }\end{array}$ \\
\hline $\begin{array}{l}\text { List as many descriptive words you know } \\
\text { about an engineer. }\end{array}$ & $\begin{array}{l}\text { List as many descriptive words you know about } \\
\text { an engineer. }\end{array}$ \\
\hline
\end{tabular}

The answers provided will capture student aspirations, interest, knowledge and effects of the activity.

\section{Classroom Activity}

The activity selected for this paper was a simple science lab that demonstrates to students the importance of percent error and percent yield in a tangible manner. The measurable is 
microwavable popcorn, thus making the materials required readily available and inexpensive as listed in Table 2.

Table 2. Material List for Activity

\begin{tabular}{|l|}
\hline \multicolumn{1}{|c|}{ Materials } \\
\hline Microwave \\
\hline Microwavable Popcorn Bags \\
\hline Plates/Paper towels \\
\hline Pen \\
\hline Paper \\
\hline Markers \\
\hline
\end{tabular}

All students were required to follow the scientific method and document their own thoughts. The experiment step was handled for the students before class in order to complete the activity in a timely manner and to establish controls. These were clearly stated to the students at the beginning of the lab. The procedure followed was to use the same microwave at the same settings for all the similar brands of bags. The importance of this was relayed to the students with further explanation provided during the data step. Students were able to work alone or in groups according to the number of bags available. When grouped, students allocated the popcorn amongst themselves and still performed individual counts of kernels and popcorn. Bag totals were performed and reported to the instructor for class totals. Calculations were performed in a class setting that allowed for trends to be identified and anomalies accounted for respectively. One trend identified was whether or not all the bags had similar kernel totals. If not, then discussion about the differences occurred often concluding in human counting error. Bag and class averages were obtained for percent yield and error and used to conclude the science portion of the activity. Table 3 lists the scientific method steps used in the activity.

Table 3. Steps of the Scientific Method

\begin{tabular}{|l|l|}
\hline & \\
\hline Question & $\begin{array}{l}\text { How many kernels popped? } \\
\text { What is the percent yield/error of the bag of popcorn? }\end{array}$ \\
\hline Hypothesis & $\begin{array}{l}\text { All of the kernels popped. } \\
10 \text { kernels did not pop. } \\
80 \% \text { of the kernels popped. }\end{array}$ \\
\hline Experiment & Materials, Procedure, and Execution \\
\hline
\end{tabular}




\begin{tabular}{|l|l|}
\hline & \\
\hline Data & $\begin{array}{l}\text { Count kernels that popped and remain. } \\
\text { Look for trends. } \\
\text { Calculate percent yield and percent error. }\end{array}$ \\
\hline Conclusion & $\begin{array}{l}\text { Was your hypothesis supported? } \\
\text { What do you think about your yield and error. }\end{array}$ \\
\hline
\end{tabular}

From the scientific method, students concluded that the percent error was too high or conversely that the percent yield was too low. A quick consensus was reached that this was not favorable due to the tangible nature of the wasted kernels that could not be eaten. The instructor simply asked is this a problem to the class with a resounding reply of yes! With this reaction an easy transition was made to launch the engineering design process with the class. The following Table 4 shows the steps taken in the engineering design method by the class.

Table 4. Steps of the Engineering Design Method

\begin{tabular}{|l|l|}
\hline & \\
\hline Problem & $\begin{array}{l}\text { Percent yield was too low. } \\
\text { Percent error was too high. }\end{array}$ \\
\hline Brainstorm & $\begin{array}{l}\text { Think of ways to improve how many kernels } \\
\text { will pop. }\end{array}$ \\
\hline Design & Select best idea and create prototype. \\
\hline Test & Do you meet the criteria, parameters, need. \\
\hline Redesign & $\begin{array}{l}\text { Adjust accordingly. Also think of cost and } \\
\text { availability. }\end{array}$ \\
\hline Report & Document final design. \\
\hline
\end{tabular}

The students were asked to make groups and to brainstorm producing at least four ideas. Many students needed to be encouraged not to simply list various cooking methods but to innovate. Ideas ranged from new packaging and materials to novel devices and differing heat sources. The heat sources included using the lasers, the sun, and digging a hole to the earth's crust. The instructor was able to further broaden students by linking their ideas to specific engineering disciplines. When students presented ideas and models involving different materials, i.e. clear wrapping, the instructor explained about how materials engineers are exploring new innovative 
methods to create more sustainable materials compared to the existing ones today. If students designed a different style bag to contain the kernels the discussion led to industrial engineering roles or mechanical engineering properties. According to the previously mentioned heat sources, engineers involved in civil, chemical and electrical disciplines were introduced. Additionally, the instructor shared her own ideas including genetically modified kernels to further broaden their grasp of engineering by mentioning agricultural. Next students were encouraged to design on paper through sketches or models of their selected idea. Lastly, discussions about how one should test then modify through redesign and finally report the final design were held by the entire class.

\section{Evaluation and Assessment}

Three cycles of classroom activity have been completed to a total of three high school science classes. At the beginning and end of the activities a quiz was administered to the students in order to collect assessment data. The quiz was designed and written by the authors in conjunction with the science teacher. The survey contained open-ended questions to encourage free expression by the students. Therefore, the survey population and sample size was 64 . A total of 57 Pre-Lab Quizzes and 46 Post-Lab Quizzes were collected and scored. Only 39 pairs of PreLab and Post-Lab Quizzes could be matched, which corresponds to a response rate of 61 percent. Survey research methods suggest that for small populations an adequate sample to provide sufficient accuracy is 50 percent of the population size. ${ }^{8}$ Since the response rate was 61 percent of the population size, the findings and observations are believed to be representative of the students who participated in the program.

The first question on the Pre-Activity Quiz aimed to gauge student career aspirations. As expected students readily identified the medical field, trades, teaching, and sports. However engineering was noted by $28 \%$ of the respondents and science by only $7 \%$. A complete list by major industry sector is shown in Table 5. This leads the authors to question whether students are correctly disassociating what are engineers.

Table 5. Student Career Aspirations

\begin{tabular}{|l|c|l|}
\hline \multicolumn{1}{|c|}{ Sectors } & $\begin{array}{c}\text { Number of } \\
\text { students } \\
\text { interested }\end{array}$ & \multicolumn{1}{|c|}{ Career Examples } \\
\hline Medical & 28 & Doctor, Nurse, Veterinarian, Physical Therapist, Pharmacist \\
\hline Business & 6 & Owner, Accountant, Manager \\
\hline Law & 9 & Lawyer, Judge, Police \\
\hline Engineering & 16 & Engineer, Electrical Engineer \\
\hline
\end{tabular}




\begin{tabular}{|l|c|l|}
\hline \multicolumn{1}{|c|}{ Sectors } & $\begin{array}{c}\text { Number of } \\
\text { students } \\
\text { interested }\end{array}$ & \\
\hline Scientific & 4 & Chemist, Forensic Scientist \\
\hline Teaching & 12 & Teacher, Math Teacher, Pre-K Teacher \\
\hline Military & 5 & Army, Navy, Marines, National Guard \\
\hline Sports & 13 & Football and Basketball Player, Coach \\
\hline Trades & 21 & Welder, Mechanic, Hair Stylist, Cosmetologist, Builder \\
\hline Computers & 5 & Game Designer, Computer Technician, Programmer \\
\hline Other & 8 & Music producer, Writer, Singer, Dancer, Truck Driver \\
\hline
\end{tabular}

Two questions that appear on both the pre and post-activity quiz allow students to freely express words that they associate with scientists and engineers. Numerous students responded with certain types and subject matter of both respectively. More interestingly were the commonly listed adjectives by the respondents shown in Table 6 .

Table 6. Commonly Listed Adjectives by Respondents.

\begin{tabular}{|l|c|c|c|c|c|}
\hline & \multicolumn{2}{l}{ PRE } & \multicolumn{2}{l|}{ TOST } \\
\hline & Scientist & Engineers & Scientist & Engineers & \\
\hline Smart & 22 & 10 & 28 & 21 & 81 \\
\hline Intelligent & 6 & 2 & 3 & 4 & 15 \\
\hline Patient & 5 & 2 & 12 & 6 & 25 \\
\hline Creative & 1 & 6 & 2 & 18 & 27 \\
\hline Hardworking & 2 & 4 & 1 & 5 & 12 \\
\hline "Hand" & 0 & 6 & 0 & 4 & 10 \\
\hline Educated & 3 & 0 & 7 & 0 & 10 \\
\hline Interest & 0 & 0 & 4 & 4 & 8 \\
\hline Fun & 2 & 0 & 3 & 1 & 5 \\
\hline
\end{tabular}




\begin{tabular}{|l|c|c|c|c|c|}
\hline \multicolumn{2}{|l|}{$|l| l|l|$} & POST & TOTAL \\
\hline Careful & 2 & 0 & 3 & 0 & 5 \\
\hline Blank & 9 & 19 & 2 & 4 & 34 \\
\hline
\end{tabular}

In all of the responses these questions were left blank 34 times, with the majority being when asked to describe engineers. This however greatly decreased after the activity was performed and by students who aspire to be an engineer. Students were also better able to describe scientist after the activity than they were before. The adjective used most to describe scientist and engineers pre and post-activity was smart. While this is not shocking, smart was used more often to describe scientists than engineers. The adjective intelligent provided similar results. Interestingly students secondly described engineers as creative, with this more than tripling after the activity. Do note that the instructor was cognizant not to use the term during the activity. Patient was another top adjective used to describe scientist and engineers, especially postactivity. Additionally, students mentioned the word hand as in handy or good with hands exclusively with engineers.

The other two questions on both the pre and post-quiz required the students to name the steps in the scientific method and engineering design process. When listing the scientific method steps only 11 of the 57 respondents could not provide a single one before the activity, reducing to none of 46 respondents to the post-activity quiz. This demonstrates a high exposure of the students to the scientific method during their education. In turn, the engineering design process steps were only mentioned by 4 respondents pre-activity with design being the step mentioned. However, only 15 respondents could not provide at least one step after the activity was finished. The totals of each step recalled by students is listed in Table 7 and Table 8 for scientific method and engineering design process respectively.

Table 7. Scientific Method Response Step Totals

\begin{tabular}{|l|c|c|}
\hline & PRE & POST \\
\hline Question & 31 & 36 \\
\hline Hypothesis & 26 & 33 \\
\hline Experiment & 29 & 33 \\
\hline Data & 14 & 25 \\
\hline Conclusion & 30 & 36 \\
\hline
\end{tabular}

Table 8. Engineering Design Process Response Step Totals 


\begin{tabular}{|l|c|c|}
\hline & PRE & POST \\
\hline Problem & 0 & 19 \\
\hline Brainstorm & 0 & 23 \\
\hline Design & 4 & 19 \\
\hline Test & 0 & 19 \\
\hline Redesign & 0 & 14 \\
\hline Report & 0 & 5 \\
\hline
\end{tabular}

The step totals for the scientific method were fairly uniform and showed improvement from the pre-activity to the post-activity quiz. The improvement on the engineering design process was much greater. The low numbers for the last step might be explained due to the lack of requirement for students to formally report during this activity.

Lastly, the authors tried to gauge if the interest of students in the fields of science and engineering was altered through the activity. Overwhelmingly respondents commented that they were more interested with some stating which specific field they had more interest. Fun was even used by students in response. Totals are provided in Table 9.

Table 9. Respondents Interest Totals.

\begin{tabular}{|l|c|c|c|}
\hline \multicolumn{1}{|c|}{ Interest } & Total & Science Only & $\begin{array}{c}\text { Engineering } \\
\text { Only }\end{array}$ \\
\hline More & 41 & 7 & 4 \\
\hline Less & 4 & & \\
\hline
\end{tabular}

Summary and Conclusion

The results of the assessment show that a majority of students participating in the activity either increased or greatly increased their awareness of and ability to identify the engineering design process. The results also show an increased awareness of and positive attitude towards engineers. This is great progress for improving the extension of engineering in STEM education at the high school level. Further application and investigation of the engineering design process in conjunction with the scientific method should be pursued in earnest.

By incorporating the engineering design process with the scientific method, and centering the design on real-world application, engineering literacy can become a relevant topic for all students. This use of the engineering design process is compatible with numerous existing 
science experiments enabling it to be expanded or contracted based on the needs of the instructor. Hopefully this will help others to include the engineering design process in their classrooms by minimizing the hurdle of developing separate activities and costs.

This paper presented the need, development, implementation, and assessment of the scientific and engineering classroom activity delivered to 64 high school students. The purpose of the activity was to increase student awareness of engineers and the engineering design process. The activity was built to parallel the engineering design process with the student's well-established scientific method. This will provide a means for teachers to infuse their existing curriculum with engineering content.

\section{Acknowledgement}

This study was made possible in part by support from the National Science Foundation GK-12 program Grant \# 0742504. The authors would like to thank Mrs. Gloria Clark for her exceptional teaching abilities and encouragement.

\section{Bibliography}

1. Brophy, S., Klein, S., Portsmore, M., \& Rogers, C. 2008. Advancing engineering education in P-12 classrooms. Journal of Engineering Education, 97(3), 369.

2. Cantrell, P., \& Ewing-Taylor, J. 2009. Exploring STEM career options through collaborative high school seminars. Journal of Engineering Education, 98(3), 295.

3. Cunningham, C., C. Lachapelle, and A. Lindgren-Streicher. 2005. Assessing Elementary School Students Conceptions of Engineering and Technology. Proceedings of the 2005 American Society for Engineering Education Annual Conference and Exposition. Portland, Ore., June 12-15. Washington, D.C.: ASEE.

4. Cunningham, C., and M. Knight. 2004. Draw an Engineer Test: Development of a Tool to Investigate Students' Ideas about Engineers and Engineering. Proccedings of the 2004 American Society for Engineering Education Annual Conference and Exposition. Salt Lake City, Utah, June 20-23. Washington, D.C.: ASEE.

5. Harris Interactive. 2004. American Perspectives on Engineers and Engineering. Poll conducted for the American Association of Engineering Societies. Final report, February 13, 2004. Available online at http://www.aaes.org/harris 2004 files/frame.htm.

6. $\quad$ Landis, R.B., "Building Student Commitment to Engineering," Proceedings of 1996 ASEE Annual Conference, Washington, D.C., June, 1996.

7. Landis, R.B., "Improving Student Success Through a Model 'Introduction to Engineering' Course," Proceedings of 1992 ASEE Annual Conference, Toledo, Ohio, June, 1992.

8. Mehalik, M., Doppelt, Y., \& Schuun, C. 2008. Middle-school science through design-based learning versus scripted inquiry: Better overall science concept learning and equity gap reduction. Journal of Engineering Education, 97(1), 71.

9. Mooney, M. A., \& Laubach, T. A. 2002. Adventure engineering: A design centered, inquiry based approach to middle grade science and mathematics education. Journal of Engineering Education, 91(3), 309.

10. Nathan, M., Tran, N., Atwood, A., Prevost, A., \& Phelps, L. 2010. Beliefs and expectations about engineering preparation exhibited by high school STEM teachers. Journal of Engineering Education, 99(4), 409. 
11. National Academy of Engineering. 2008. Changing the Conversation. Washington D.C.: The National Academies Press.

12. National Academy of Engineering. 2002. Raising Public Awareness of Engineering. L. Davis and R. Gibbin, eds. Washington, D.C.: The National Academy Press

13. Prussia, S. E., \& Birmingham, D. M. 2000. (R3)+(D3)=A learning tool for science and engineering. Journal of Engineering Education, 89(4), 435.

14. Rea, L., and R. Parker. 1997. Designing and Conducting Survey Research. 2nd edition. San Francisco, CA: Jossey Bass.

15. Silk, E. M., Schunn, C. D., \& Cary, M. S. 2009. The impact of an engineering design curriculum on science reasoning in an urban setting. Journal of Science Education \& Technology, 18(3), 209-223.

16. Tate, D., Chandler, J., Dean Fontenot, A., \& Talkmitt, S. (2010). Matching pedagogical intent with engineering design process models for precollege education. AI EDAM, 24(3), 379-395.

17. Tran, N., \& Nathan, M. 2010. Pre-college engineering studies: An investigation of the relationship between pre-college engineering studies and student achievement in science and mathematics. Journal of Engineering Education, 99(2), 143. 